\title{
Transformational Leadership Practices in Curriculum Implementation (Environmental Education) in Secondary Schools in Siaya County, Kenya
}

\author{
Ursulla A. Okoth \\ University of Nairobi, Kenya
}

Doi: 10.19044/esj.2018.v14n10p320 URL:http://dx.doi.org/10.19044/esj.2018.v14n10p320

\begin{abstract}
Leadership practices promote accomplishment of goals in organizations. This paper focuses on the application of transformational leadership practices: Idealized influence, Inspirational motivation, Intellectual stimulation and Individualized consideration in curriculum implementation, Environmental Education (EE). The sample consisted of 183 teachers randomly selected from 30 secondary schools in Siaya County. A questionnaire was used in a descriptive survey research. The findings using the selected indicators were that head teachers: strived towards the collective goal of fulfilling a vision and were positive role models; had trust of teachers' ability; made decisions all the time; encouraged students to work hard; and organized meetings with other schools to achieve subject objectives.
\end{abstract}

Keywords: Leadership practices, curriculum implementation, Environmental Education, Kenya

\subsection{Introduction}

For any educational programme to succeed, there must be effective leadership and instruction. The instructional leadership functions include setting academic standards, providing incentives for learning, and providing incentives to teachers. The head teachers promote teachers' sense of efficacy, sense of community, professional interest and development, and instructional improvement. Good education leaders keep students' learning at the centre of their work no matter what task or activity they undertake (Association for Supervision and Curriculum Development (ASCD), 2002). Instructional Leadership and curriculum development is the core function of the head teacher (Hallinger \& Murphy, 1986; Edmonds, 1979). Head teachers determine how to implement standards and decide on what to emphasize and what to omit (Wolf, Borko, Elliot, \& McIver, 2000). 
Studies have been carried out to investigate leadership behaviour that enhances academic achievement and curriculum implementation. In the 1990s, leaders were expected to bring about transformational leadership which was seen as a superior mode of leading. This article presents transformational leadership theory as a basis for effective implementation of curriculum (Environmental Education, EE) in secondary schools. Although EE is infused in other subjects in secondary school curriculum, it is important that the essence of keeping a healthy environment for sustainable development is upheld (KIE, 2002).

\subsection{Transformational Leadership}

Transformational Leadership Theory refers to a process of change in individuals. The term was first used by Downton in 1973 and later advanced by Burns in 1978 as a leadership approach. According to transformational leadership theory, the leader and followers engage in a mutual process of raising one another to higher levels of morality and motivation (Burns, 1978). By raising appeal to higher ideals transformational leadership theory, transformational leadership enables the leaders and followers to focus on intangible qualities such as vision, shared values and ideas which provide common ground for the change process. Transformational leadership is based on personal values, beliefs, and qualities of the leader which include charisma. According to Bass (1985), followers are influenced to trust, admire, and respect the leader.

\subsection{Weaknesses of Transformational Leadership Theory}

Unlike alternative leadership practices, the use of charisma in educational institutions may evoke strong emotions causing concern about moral and ethical issues of the leader (Bass, 1985). Dependence on the leader's abilities as the yardstick by which followers measure their own performance is deceptive and has a high potential of being abused or causing leadership derailment (Daft \& Marcic, 2006). Transformational leadership can be undemocratic and elitist, but Bass and Avolio (1993) argued that transformational leaders can be participative. Transformational leadership is interpreted as a personality trait and fails to occur along a continuum as it covers many parameters (Northouse, 1997). This implies that it is dependent on one individual, the principal of the school.

\subsection{Strengths of Transformational Leadership Theory}

Transformational leadership model grounded on moral foundations would result in idealised influence, inspirational motivation, intellectual stimulation, and individualised consideration required in an effective instructional leader. Daft (2008) contends that transformational leadership brings about significant 
change in both followers and the organisation. The followers are inspired through increasing awareness of task, focusing on team goals, and activating the higher order needs. Transformational leadership in a school set-up develops followers such as teachers into leaders, elevates followers' concerns from lower level needs to higher needs, inspires followers to go beyond their self interest for the good of the community, and points a vision of a desired future state and communicates change well.

Transformational leadership is widely researched and conforms to society's belief that leaders should provide a vision. Transformational leadership focuses attention on needs, values, and growth of followers; hence, it values the commitment and capacities of organizational members (Leithwood, Jantzi, \& Steinbach, 2000). Transformational leadership shows a marked departure from a top-down management approach, including deeper targets for more sustainable change and a shift from managerial or transactional relationships with the staff (Hallinger, 2003). This approach re aligns managers to involve employees in decision making and creating partners which promotes positive attitudes and superior desires leading to acceptance of leaders and lowering of absenteeism. The advantages of transformational leadership out-weigh the disadvantages and are associated with effective instructional leaders. Daft and Marcic (2006) and Northouse (1997) opined that transformational leadership is the basis for modern learning organisations in both business and schools.

\section{Application of Theory}

\subsection{Application of Transformational Leadership Theory to Instructional Leadership}

As an instructional leader, the head teacher is the pivotal point within the school who affects the quality of individual teacher instruction, the height of student achievement, and the degree of efficiency in school functioning (Silins, Mulford \& Zarins, 2002; Leithwood \& Jantzi, 1999; 2000; Hallinger \& Murphy, 1986; Edmonds, 1979). Darling-Hammond (2003) stated that transformational leadership style helps to develop a positive school culture in which teachers become interested in the interactions at their schools as they participate all the time.

The head teacher represents a master teacher who primarily increases the level of student achievement. As the immediate supervisor, the head teacher ensures punctuality and effective performance of duty by fostering selection, development, use, and evaluation of appropriate Environmental Education instructional materials and processes. According to Berends, Bodilly, and Nattaraj (2002), effective and supportive principal leaders were most likely to increase and deepen the implementation of school improvement initiatives. 
The instructional leader needs to be good at traditional management functions such as planning and budgeting, and to focus on the impersonal aspects of job performance (Okumbe, 2007; Everard, Morris, \& Wilson, 2004). Teachers and support staff should receive rewards for enhancing environment, whereas the leader benefits from meeting Environmental Education tasks. Though researchers Edmonds (1979) and Flath (1989) stressed the importance of the instructional leadership responsibilities of the head teacher, the consensus in the literature indicate that it is seldom practiced (Flath, 1989). Stronge (1988) found that 62.2 percent of the elementary head teacher's time is focused on school management issues, whereas only 6.2 percent of their time is focused on programme issues. Wafula (2007) found that teacher's records were checked by some Heads of Department.

Flath (1989.20) categorises instructional leadership activities as goal emphasis, coordination and organization, power and discretionary decisionmaking, and human relations which apply to Environmental Education. The leader is sensitive to working with teachers, and members of the public (Baskett \& Miklos, 1992). According to King (2002), head teachers would assist Environmental Education implementation by hosting meetings for teachers to discuss any gaps they may find in Environmental Education teaching and learning. The forum for teachers and administrators help to identify problems with the technology of education as a foundation for considering how to move forward and how to deal with the gaps identified.

The head teachers invite outside experts to provide teachers an overview of the research about Environmental Education teaching and learning so that they can contextualize the situation in their school within a larger framework. This allows teachers to come to grips with Environmental Education challenges confronting them in a way that they can better deal with these challenges. The head teachers assist teachers to focus more intently on their work by organizing peer visits as well as data gathering. In this way, teachers develop a data base for benchmarking the current Environmental Education situation and to assess progress or lack thereof.

King (2002) stated that collaboration of the teachers, head teacher, and administrators build leadership density in schools and provide the conditions which facilitate the development of teachers as leaders in the areas of curriculum, learning, and teaching. Barth (2001) notes that success in these endeavour positions teachers to make decisions in many areas that were once reserved to the head teacher. These include: choosing textbooks and instructional materials; shaping the curriculum; setting standards for student behaviour; designing professional development and in-service programmes; and deciding school budgets. According to Smylie and Conyers (1991), teachers are instructional experts and the head teacher should encourage the development of their instructional leadership to improve instruction quality. 
Checkley (2000) asserted that by promoting a forum for professional discourse, head teachers as instructional leaders construct a school culture through which teachers redefine curriculum, teaching and learning, translating it into new classroom practices as they build relationships characterized by mutual trust, risk taking, and experimentation. Hence, this all takes place in a supportive and professionally challenging environment.

\subsection{Application of Transformational Leadership Theory to Instruction of EE}

Transformational Leadership Theory is applied to instructional leadership in the implementation of EE because transformational leaders bring change in attitudes, skills, and knowledge among teachers and students for environment protection. Transformational leadership is a conscious leadership regardless of the situation. Its goal is to change institutions and not simply to have things done. Transformational leaders have ways to make followers trust their performing behaviours that contribute to achievement. Due to leaders' charisma, their vision of how good the environment could be if protected is well communicated through their own excitement that induces followers to support their vision. However, they have high levels of self confidence and esteem which cause followers to respect and admire them (Daft \& Marcic, 2006). The leader also widens the needs of the followers and supports them to achieve higher needs (Antonakis, Cianciolo, \& Sternberg, 2004). The students and teachers are likely to view environment issues differently, making them feel some degree of responsibility to solve problems, for example, picking and placing litter in a correct place. According to Fullan (1991), head teachers influence the extent of implementation by playing a direct active role than leaving the implementation process to individual teachers. Although they may not be experts in the area, they provide leadership by familiarising with the general nature of the 'subject' and through working with staff to become effective.

Ross and Gray (2006) found that transformational leadership behavior is positively correlated with high academic performance in schools. The high performance was due to the head teachers' building of teachers' professional commitments and belief in their collective capacity, and motivating them to go beyond self-interest and embrace organizational goals. Transformational leadership, therefore, influences teachers' commitment to school's vision, professional community, school norms of collegiality, collaboration, and team work. It implies that such leaders have the tendency to inspire teachers to think beyond their own interests and focus on organizational and national objectives.

According to Okoth (2008), the relationship between Transformational Leadership practices, Teacher Commitment and School Outcomes can be 
conceptualized as an Input-Process-Output (IPO) Model based on Bass theory of 1985 as follows: Input is the head teacher's leadership practices. The first is the idealized influence, where the leader acts as a role model; the second is the inspirational motivation, where the leader usually evokes enthusiasm and a team spirit of shared purpose; the third being intellectual stimulation which challenges all to explore options and innovative approaches; and finally the individualized stimulation which lends value to all individuals within the organization (Bass, 1998).

Process is the instructional role of teachers who are encouraged to be enthusiastic, to exhibit awareness of task \& need for personal growth; and commitment of teachers to school system over personal interest. According to Bass (1985), the leader induces followers to support their vision and put aside self interest for the sake of the organisation. It means head teachers take responsibility for helping to solve problems as they grow in the process. The leader's energetic, enthusiastic, and oral communication helps people to understand real life issues. It is assumed that the head teacher is a professionally qualified teacher with the pedagogic skills to implement Environmental Education. Bass (1985), Hallinger and Murphy (1986), and Leithwood and Jantzi (2000) provided variables used; for example, the head teacher projects him/herself as a role model, and strives towards the collective goal of fulfilling a vision.

Output are the outcomes which include positive EE attitudes, EE knowledge and skills, institution enthusiastic about EE issues, and positive behavior.

Over the years, work on transformational leadership has focused on other variables. According to Kouzes and Posner (1989; 2007), five common practices of transformational leadership are: model the way, which involves clarifying values and setting the example; inspire a shared vision, which involves envisioning the future and enlisting others; challenge the process, which involves searching for opportunities, experimenting, and taking risks. Through these, teachers are stimulated to achieve more for themselves and their students as they aspire higher levels of performance. In 1996, Leithwood came up with six specific principals' behaviour which are: Identifying and articulating a vision, providing an appropriate model, fostering the acceptance of group goals, providing individualized support, providing intellectual stimulation, and holding high performance expectations (Jantzi \& Leithwood, 1996). Therefore, the objectives based on Bass Transformational Leadership Model are:

i. To establish how Charismatic/ idealized influence affects principals' curriculum implementation (EE) in secondary schools;

ii. To determine influence of Inspirational motivation on principals' curriculum implementation (EE) in secondary schools; 
iii. To establish how Intellectual stimulation influence principals' curriculum implementation (EE) in secondary schools;

iv. To determine the extent to which Individualized consideration of principals affect curriculum implementation (EE) in secondary schools.

\section{Methodology}

A descriptive survey design was used. The sample consisted of six boys, six girls, and 18 mixed schools obtained by stratified random sampling. A total of 183 teachers were obtained by random sampling from the selected 30 schools. (Kothari, 2008; Mugenda, 2008). The Teachers' questionnaire was administered in person after obtaining a permit from National Council of Sciences, Technology and Innovation (NACOSTI). Validation was done by pre-testing the instruments in a pilot study and reviewed by experts in educational administration. Reliability was determined using test-retest method resulting in $\mathrm{r}=0.8$.

\section{Indicators of Leadership Practices}

Idealized Influence: Strive towards the collective goal of fulfilling a vision and role model;

Inspirational Motivation: Trust of teachers' ability to deal with obstacles;

Intellectual Stimulation: Make decision all the time; and

Individualized Consideration: Encourage students to work hard, be present in school, and organize meetings with other schools.

\section{Findings and Discussions}

\subsection{Idealized Influence}

i. Leaders are expected to identify and articulate a vision, and to foster the acceptance of group goals. The teachers were asked to rate the head teachers' efforts towards the collective goal of fulfilling a vision. The results show that majority of the teachers agreed (strongly agree 43.2 percent and agree 38.4 percent), while those with no opinion was 10.9 percent. Those who disagreed that heads strive to achieve goals were at 3.8 percent, and the least 2.7 percent strongly disagree. As leaders, head teachers strive towards the collective goal of fulfilling a vision.

ii. Positive role modelling has been cited as the best method to influence others by practising what they see. Authentic leaders build their practice outward from their core commitment, making them role models for enhancing environmental education. Teachers rated how they perceived their heads as role models. The results show that most of the teachers 45.3 percent strongly agree and 39 percent agree that the head teachers acted as role models. 
However, 6.0 percent teachers strongly disagree and 3.8 percent disagree that head teachers act as role models, while 6.0 percent had no opinion.

\subsection{Inspirational motivation}

Leaders often inspire those under them by being enthusiastic about what they do. Teachers can be motivated through attending seminars which empowers them in various ways. They may acquire specific skills which would inspire them and develop positive attitudes. Teachers were asked to rate head teachers' belief that teachers could deal with obstacles they came across while implementing curriculum. The findings show that majority of the teachers 43.2 percent agreed, and 41 percent strongly agreed. The rest, 6.0 percent, disagreed and 3.8 percent strongly disagreed that head teachers believed in teachers' ability to deal with obstacles. Another 6.0 percent had no opinion.

\subsection{Intellectual Stimulation}

The transformative leadership practices made leaders to encourage workers to explore options and come up with innovative approaches to solve problems. This would make teachers to explore methods of teaching that would enhance retention of knowledge and application of skills learnt. It also helps in the decision making process whereby teachers makes use of best methods and resources while teaching. The teachers were asked about the ability of the head teacher to cope with decision making. The majority of teachers 52.5 percent agreed and 36.6 percent strongly agree. Thus, the data illustrates that majority of the head teachers are capable of making decisions regarding curriculum (Environmental Education), but there is room for improvement for 4.4 percent who disagree, 1.8 percent who strongly disagree, and 6 percent who had no opinion. Although the heads may not know the details of the syllabus, they still guide teachers as they consult subject experts (Fullan, 1991).

\subsection{Individualized Consideration}

Individual attention paid to workers makes them feel valued. The individualized consideration lends value to all individuals within the organization and is a source of job satisfaction. There are three items in this section: encourage students to work hard, discussing with teachers from other schools, and heads' presence in school.

i. The results on whether the head teachers encourage students to work hard in Environmental Education showed that most teachers agreed (36.1 percent strongly agreed and 32.2 percent agreed). Meanwhile, 8.2 percent disagreed, 4.9 percent strongly disagreed head teachers encourage their 
students, and 18.6 percent had no opinion. The results suggest that head teachers encourage students to work hard but more needs to be done.

ii. Benchmarking is important as it makes people learn from others at the same level. Teachers were asked about head teachers organising meetings with other schools for Environmental Education. The results show that majority of teachers agree (44.8 percent strongly agree and 28.4 percent agree) that head teachers organise meetings with other schools. This could be in view of joint examinations previously done in the districts as well as sports. However, 9.8 percent teachers disagree and 7.7 percent strongly disagree that head teachers ever organise meetings with other schools, while 9.3 percent had no opinion. Kouzes and Posner (1989) and Checkly (2000) commended such meetings for the improvement of the working culture in the schools; enable others to act by fostering collaboration and strengthening others; encourage the heart by recognizing others' contributions and creating a spirit of community.

iii. The teachers were asked about the importance of the head teachers' presence in the school. The results showed the highest proportion of teachers: 36.1 percent said they agree, 31.7 percent strongly agree, 17.5 percent had no opinion, 9.8 percent disagree, and 4.9 percent strongly disagree. The results indicate 67.8 percent teachers perceive that the presence of the head teacher in school is important. Mbiti (2007) concurs that the head teacher's presence in school is significant.

\section{Conclusion}

Applying idealized influence, head teachers strive towards the collective goal of fulfilling a vision and acting as role models. Applying Inspirational motivation, head teachers trust teachers' ability to deal with obstacles in curriculum. Intellectual stimulation prompts the head teacher to make decisions even through the practice of consultation. For Individualized consideration, head teachers encourage students in person to work hard and they also organize meetings with other schools.

\section{Implications and Recommendations}

i. The Head teachers should be encouraged to use transformation leadership practices as they improve on curriculum implementation and management. The Teachers Service Commission (TSC) and Ministry of Education (MoE) should ensure that aspiring and practicing head teachers receive continuous training as a policy.

ii. Kenya Education Management Institute (KEMI) should design curriculum for leadership development for head teachers to apply transformational leadership practices. This is the institution mandated by MoE for teacher development. 
iii. Leaders should strive towards the collective goal of fulfilling a vision so that they can personally be enthusiastic to accomplish objectives.

iii. Head teachers should develop positive attitudes about the teachers' abilities on curriculum instruction and decision making while they provide support.

iv. Head teachers should encourage teachers and students in person to work hard and benchmark with other schools.

\section{References:}

1. Antonakis, J., Cianciolo, A., \&Sternberg, R. (2004). The nature of leadership. Thousand Oaks: Sage Publications Inc

2. Baskett, S., \& Miklos, E. (1992). Perspectives of effective head teachers. Canadian Administrator, 32 (1) 1-10.

3. Bass, B.M. (1998). Transformational leadership: Industrial, military, and educational impact. Mahway, NJ: Lawrence Erlbaum Associates.

4. Bass, B. M. (1985). Leadership and performance beyond expectations. New York: Free Press.

5. Bass, B. M., and Avolio, B. J. (1993). Improving organisational effectiveness through transformational leadership. Thousand Oaks, CA: Sage publications.

6. Berends, M., Bodilly, S. J., \& Nataraj-Kirby, S. (2002). Facing the Challenges of Whole-School Reform (No. MR-1498-EDU). Santa Monica, CA: Rand Corporation.

7. Burns, J. M. (1978). Leadership. New York: Harper and Row

8. Checkley, K. (2000, May). The contemporary principal: New skills for a new age. Education Update, 43 (3) 1, 4-6, 8.

9. Daft, R. L. (2008). The Leadership experience $\left(4^{\text {th }}\right.$ ed.). Mason: Thomson South Western.

10. Daft, R. L. \& Marcic, D. (2006). Understanding management (5 $5^{\text {th }}$ ed.). Mason, US: Thomson South Western.

11. Darling-Hammond, L. (2003). Keeping good teachers: Why it matters, what leaders can Do. Educational Leadership, 60(8), 6-13.

12. Day, C. (2000). Beyond transformational

13. leadership. Educational Leadership, 57 (7), 56-59.

14. Downton, J. V. (1973). Rebel leadership: Commitment and charisma in a revolutionary process. New York: Free Press

15. Edmonds, R. R. (1979). Effective schools for the urban poor. Educational Leadership, 37, 15-27.

16. Everard, K.B., Morris, G., and Wilson, I.(2004).Effective school management ( $4^{\text {th }}$ ed.). London: Paul Chapman Publishing co.

17. Flath, B. (1989). The principal as instructional leader. ATA Magazines, 69 (3), 19-22, 47-49. 
18. Fullan, M. (1991). The new meaning of educational change. New York: Teachers College Press.

19. Hallinger, P.(2003). Leading educational change: Reflections on the practice of instructional and transformational leadership. Cambridge Journal of Education, 33(3), 329-351.

20. Hallinger, P. and Murphy, J. F. (1986). The social context of effective schools. American Journal of Education of Education, 94 (3) 328-355.

21. Kenya Institute of Education (2002). Secondary school syllabus. Volume 3 Nairobi: Jomo Kenyatta Foundation.

22. King, D. (2002, May). The changing shape of leadership. Educational Leadership, 59 (8), 61-63.

23. Kothari, C. R. (2008). Research methodology. (2 ${ }^{\text {nd }}$ revised ed.). New Delhi: New Age International (P) Limited.

24. Kouzes, J.\& Posner, B. (1989). The leadership challenge: How to get extraordinary things done in organizations. San Francisco, CA: Jossey-Bass.

25. Kouzes, J. M. \& Posner, B. Z. (2007). The leadership challenge. $\left(4^{\text {th }}\right.$ ed.). San Francisco: Jossey-Bass.

26. Leithwood, K. (1994). Leadership for school restructuring. Educational Administrational Quarterly, 30 (4) 498-518.

27. Leithwood, K. \& Jantzi, D. , (2000). The effects of transformational leadership on organisational conditions and student engagement with school. Journal of Educational Administration Quarterly, 38 (2) 112129.

28. Leithwood, K. \& Jantzi, D. (1999). The relative effects of principal and teachers' sources of leadership on student engagement with school. Journal of Educational Administration Quarterly, 35 p 269-706.

29. Leithwood, K., Jantzi, D. \& Steinbach, R. (1999). Changing leadership for changing times. London: Open University Press.

30. Mbiti, D. (2007). Foundations of administration. Nairobi: Oxford University Press.

31. Mugenda,G.A. (2008). Social science research. Theory and principles. Nairobi: Applied Research and Training Services.

32. Northouse, P.G. (1997). Leadership. Theory and practice. London: Sage Publications.

33. Okoth, U.A. (2008). Instructional leadership role of head teachers in the implementation of secondary school Environmental Education in Siaya District, Kenya.

34. Okumbe, J. A. (2007). Educational management. Theory and Practice Nairobi: University of Nairobi Press (reprint). 
35. Republic of Kenya (2004). Consultation report 2001-2004 Siaya District, Poverty Reduction Strategy Paper (PRSP). Nairobi: Government Printer.

36. Ross, J. A. \& Gray, P. (2006). Transformational leadership and teacher commitment to organizational values: The mediating effects of collective teacher efficacy. School Effectiveness and School Improvement, 17(2), 179-199.

37. Silins, H.C., Mulford, W.R, \& Zarins, S. (2002). Organizational learning and school change. Educational Administration Quarterly, 38 (5) 613-642.

38. Smylie, M., \& Conyers, J. (1991). Changing conceptions of teaching influence the future of staff development. Journal of Staff Development, 12 (1) 13.

39. Stronge, J. H. (1988). A position in transition? Principal, 67 (5) 32-33.

40. Wafula, J.A. (2007). Teachers' perceptions on the role of Quality Assurance and Standards on quality of education in Nairobi Province. Unpublished M.Ed Project. Nairobi: University of Nairobi 